\title{
Nud locus and the effects on seedling vigour related traits for genetic improvement of hulless barley
}

\author{
Ludovic Capo-chichi ${ }^{1}{ }^{2 *}$, Kimberly Kenward ${ }^{1}$, Joseph Nyachiro ${ }^{3}$, and Anthony Anyia ${ }^{2}$ \\ Correspondence: Ludovic.Capo-chichi@albertainnovates.ca \\ 120/20 Seed Labs Inc, \# 201 - 50911 Avenue, Nisku, AB, Canada. \\ ${ }^{2}$ Alberta Innovates - Technology Futures, P.O Bag 4000, Vegreville, AB, Canada. \\ ${ }^{3}$ Alberta Agriculture and Rural Development, Field Crop Development Centre, 5030 - 50 Street, Lacombe, Canada.
}

\begin{abstract}
Some hulless barley varieties have been reported to be associated with poor vigour, which can limit their yield and make them unattractive to growers. A study was conducted to determine the linkage relationship of the locus nud conditioning hullessness and other loci controlling the expression of the seedling vigour related traits. Recombinant inbred lines (RILs) were generated from a cross between spring type varieties with contrasting seedling vigour. These two parental lines differ in seedling growth habit, with 'CDC Cowboy', a hull type (N/_), possessing superior seedling vigour and 'CDC Rattan', a hulless type $(n / n)$, exhibiting poor seedling vigour. Early vigour was assessed as leaf areas and specific leaf areas at the 3rd leaf stage. The traits considered to contribute to early vigour were: leaf width, leaf area, leaf dry weight, and specific leaf area of the first and second leaves. Each of the traits showed continuous variation among the hulless RILs. Transgressive segregation was distinctly observed for all traits. Canonical discriminant analysis (CDA) revealed that the hullessness, controlled by the recessive gene $(n / n)$, may not have an epistatic effect on several other loci, including those controlling the expression of seedling vigour related traits. This suggests that it is possible to develop hulless types of barley varieties with improved seedling vigour. The present study represents the first step in development of a marker-assisted breeding effort to improve early-season performance in hulless barley.
\end{abstract}

Keywords: Barley, seedling vigour, heritability, genetic variability, hulless gene, recombinant inbred lines (RILs)

\section{Introduction}

Spring barley (Hordeum vulgare L.) is widely grown throughout the Canadian prairies. Soil moisture in these areas is usually high at the time of seeding but becomes limited over the mid and late part of the growing season. Physiological studies of spring barley in water-limited environments have identified several traits that appear to contribute to a more efficient use of available soil water, and thereby increase productivity. Early seedling vigour is one of these traits $[\mathbf{1 , 2 , 3 ]}$.

Differences in early seedling vigour in cereals have been reported to be associated with variation in specific leaf area (SLA), leaf width (LW), and leaf area (LA) of seedling leaves, along with embryo size $[4,5,6,7]$. The width of the first seedling leaf has been found to integrate the embryo size and can be an indirect estimate of early seedling vigour of cereals [5]. SLA and its inverse, specific leaf weight (SLW) of the first leaves have been found to be correlated with early seedling vigour $[\mathbf{8}, \mathbf{9}]$, suggesting that SLA is suitable for selecting plants with high early seedling vigour [10]. Previous studies reported that high early seedling vigour allows the plant to close the leaf canopy at minimal carbon expense [11]. As canopy closure improves the water use efficiency of small-grain cereals, as suggested by [2], the maximization of leaf area by increasing the SLA may be important in plant breeding for increasing water use efficiency. In addition, the authors found that the width of the first or second seedling leaf is strongly and positively correlated with early seedling vigour. Therefore, leaf width may be used to select for varieties with rapid leaf development and early seedling vigour $[12,13]$. Although seedling vigour can be influenced by many other factors, in this study we focused on the traits related to specific leaf area. The effects of major genes on quantitative traits have been shown in barley, where $V$ locus has pleiotropic effect on height and biomass production [14]. Vrs1 is the gene controlling two-row/six row $[15,16]$ and the nud locus is for hulled/hulless $[17,18,19]$. In a replicated trial of hulless and hulled double haploid lines derived from a single hulled $x$ hulless cross, the presence of the nud gene has been found to be associated with reduced plant height, lower plant density, lower seed weight, higher test weight, and yield reduction [19]. The hulless barley is governed by a

(C) 2012 Capo-chichi et al; licensee Herbert Publications Ltd. This is an open access article distributed under the terms of Creative Commons Attribution License (http://creativecommons.org/licenses/by/3.0),This permits unrestricted use, distribution, and reproduction in any medium, provided the original work is properly cited. 
recessive gene, which in a homozygous condition has been shown to have an epistatic effect on several loci, including those controlling the expression of thickness of leaves; culm diameter; number of internodes; panicle size; and number of days to anthesis and to maturity [20]. Previous reports showed that hulless barley yielded less than covered barley [21]. On the other hand, a hulless mutant yielded as much as the covered parent [22]. They also showed that the change of a single gene by radiation to result in a hulless kernel was consistently associated with shorter stems and longer rachis internodes. In spring type oat (Avena sativa L.), studies showed that the expression of the hulless trait is effected by environmental conditions [23,24]. An incompletely dominant gene (N1), interacting with modifying genes, controls the hulless characteristics in oats $[\mathbf{2 3}, \mathbf{2 4}]$. However, the effect of the nud gene on seedling vigour related traits in barley such as specific leaf area, leaf area, and leaf length has not been thoroughly investigated. It is true that hulless types have generally poorer crop establishment due to damage to the exposed embryo during harvest. Determination of correlation coefficients between seedling vigour related traits is important to select favourable plant types. As direct selection for various traits could be challenging, indirect selection via related traits with high heritability might be more effective [25]. Traditionally, univariate analysis such as correlation and regression analysis have been used in determining traits' interrelationships [26]. However, when considering many traits simultaneously, overlapping may occur since each variable is viewed separately. In canonical discriminant analysis, all independent variables are considered simultaneously for the differentiation of individuals, resulting in a more distinct population differentiation than univariate analysis. The overall objective of this study was to 1) evaluate the heritability and genetic variability in specific leaf area, leaf area, and leaf length in a population of recombinant inbred lines of barley and 2) assess the effects of the Nud locus on these traits.

\section{Materials and methods}

\section{Genetic materials}

Recombinant inbred lines (RILs) were developed from a cross between two-rowed barley varieties: CDC Cowboy, a hulled barley variety and CDC Rattan, a hulless barley variety possessing relatively high $\beta$-glucan content. The two parents, developed at the Crop Development Centre in Saskatchewan, Canada, differ in seedling growth habit with CDC Cowboy having superior early seedling vigour compared to CDC Rattan, under both field and greenhouse environments. Two hundred random $\mathrm{F}_{2}$ plants of this cross were self pollinated and advanced to the $F_{5}$ generation by single-seed-descent method. Self pollinated seeds from each of the inbred plants were grown in $\mathrm{F}_{5-6}$ progeny rows. As major genes effect many quantitative traits $[27,28,14]$, they may interfere with the ability to detect other quantitative traits. Taking into consideration that the hulled caryopsis allele (Nud) is dominant over the hulless, the RILs population was separated into two sub-populations. Naked caryopsis (hulless) in barley is characterized by complete detachability of the hulls (lemma and palea) on threshing, whereas in covered (hulled) barleys, the hull remains completely attached with the grain on threshing, making facile the phenotypic screening of lines. The hulless RILs, controlled by a recessive gene, which in a homozygous condition has been shown to affect the expression of several traits, were compared to the parental lines including CDC Rattan and CDC Cowboy.

\section{Experimental design and phenotypic data}

The experiment was conducted in Vegreville (Longitude/ Latitude: $112^{\circ}-03^{\circ} \mathrm{W} / 53^{\circ}-30^{\circ} \mathrm{N}$ ), under well-drained soil developed on fluvial-lacustrine material over till (Malmo series of an Eluviated Black Chernozem) in Alberta, Canada. All lines were grown in replicated field plots in Vegreville using randomized block design with three replicates. The row was 2 meters long and the plants were spaced at $0.2 \mathrm{~m}$. Seeding rate was 215 seeds per square meter. The greenhouse experiment consisted of one single plant per pot with five replicates. Plants were grown within adequate nutrition and irrigation up to the fifth leaf stage at which time the leaves were sampled for seedling characteristics. Leaf length (LL) and LW were measured on the first and second leaves. Leaf dry weight (LDW) was determined after oven-drying at $70^{\circ} \mathrm{C}$ for $48 \mathrm{~h}$. Leaf area was calculated from the product of the length by width of leaves, correcting for leaf shape using a correction factor of 0.8 [13]. SLA was determined as the ratio of leaf area to dry weight of the first two main stem leaves.

\section{Data analysis}

Analysis of variance was performed using PROC GLM procedure of SAS [29]. Mean separation was done by Fishers LSD $a=0.05$. Heritability $\left(H^{2}\right)$ on an entry mean basis was estimated from the genetic and error variance components using the formula:

$$
H^{2}=\sigma_{g}^{2} /\left[\sigma_{g}^{2}+\left(\sigma_{\varepsilon}^{2} / r\right)\right]
$$

where $\sigma_{g}^{2}$ is the genetic variance, $\sigma_{\varepsilon}^{2}$ is the residual error variance and $r$ is the number of environments. Pearson's correlations between pairs of traits were determined with the function PROC CORR in SAS. Significant correlations with $0.2 \leq r^{2} \leq 0.5,0.5<r^{2} \leq 0.8$ and $0.8<r^{2}$, were considered weak, moderate and strong, respectively. Canonical discriminant analysis (CDA) was used to differentiate the two subpopulations corresponding to the alleles at the nud locus. It was performed with the function PROC CANDISC in SAS. It facilitates differentiation of the sub-populations by taking into account the interrelationships of the independent variables (traits) and the dependable variables (RILs and sub-populations). Canonical correlation analysis, developed 
by [30], often allows a more meaningful interpretation of interrelations between variables than simple correlation and multiple regression analyses. Unlike univariate statistical techniques which do not show how individuals within populations differ when all variables (traits) are considered together, canonical discriminate analysis simultaneously examines the differences in the seedling vigour related traits and indicates their relative contribution [31].

\section{Results}

\section{Environmental variation}

The two parental varieties, CDC Cowboy and CDC Rattan, showed significant differences in LW, LA, SLA, and LDW of the first and second seedling leaves under greenhouse and field environments (Table 1). CDC Cowboy showed the highest values for all traits, suggesting that it has the greatest seedling vigour, while the lowest seedling vigour was shown in CDC Rattan. Combined analysis of field and greenhouse environments indicated that there were differences among both RILs and environments $(P<0.001)$. Seedlings grown in the greenhouse had significantly $(P<0.001)$ larger LA, LW, and SLA than seedlings grown in the field (Table 1). The width, LA, and SLA of the first seedling leaf of RILs mean values were $7 \%, 13 \%$ and $23 \%$ greater for greenhouse-grown than field-grown plants, respectively. The width, LA, and SLA of the second seedling leaf of the RILs means were $14 \%, 16 \%$, and $11 \%$ greater for greenhousegrown than field-grown plants. Genotype, environment and their interactions have contributed to the phenotypic variation for LW, LA, and SLA of the first and second seedling leaves.

\section{Phenotypic distribution of seedling vigour related traits}

Each of the traits examined showed continuous variation (Figure 1). The range in LW1, LA1, and SLA1 of hulless RILs was $0.54-0.90 \mathrm{~cm}, 3.22-6.61 \mathrm{~cm}^{2}$, and $181-302 \mathrm{~cm}^{2} . \mathrm{g}^{-1}$, respectively (Table 2 ), while among the hulled RILs, the values were $0.54-0.82 \mathrm{~cm}, 2.93-6.34 \mathrm{~cm}^{2}, 150-279 \mathrm{~cm}^{2} . \mathrm{g}^{-1}$, respectively. A similar trend was observed for LW2, LA2, and SLA2 (Table 2). On average, the hulless RILs produced high values for all traits, similar to the hulled RILs (Table 2). The nud locus seems to have no pleiotropic effect on the seedling vigour related traits because the traits of some hulless lines were relatively high. The highest values for LW, LA, and SLA of the first leaf were also observed in the hulless RILs (Table 2).

Genotypic difference between parental lines translated into significant differences among the hulless RILs. Each of the traits examined showed continuous variation among the RILs (Table 2). Mean values for all seedling vigour related traits showed evidence of transgressive segregation, as indicated by lower minimum and higher maximum trait values of the RILs when compared to the trait values measured for the parental lines. The exception to this is SLA1 in the hulled RILs where the highest value is less than the mean value of CDC Cowboy (Table 2, Figure 1).

Table 1. Average, minimum (min) and maximum (max) values and trait heritability of CDC Cowboy, CDC Rattan and hulless RILs for the following traits. The experiment was conducted under field and greenhouse conditions.

\begin{tabular}{|c|c|c|c|c|c|c|c|c|c|c|c|c|}
\hline \multirow[t]{3}{*}{ Trait $\$$} & \multirow[t]{3}{*}{ Environment } & \multicolumn{4}{|c|}{ Parental lines } & \multicolumn{7}{|c|}{ RILs } \\
\hline & & \multicolumn{2}{|c|}{ CDC Cowboy } & \multicolumn{2}{|c|}{ CDC Rattan } & \multirow[b]{2}{*}{ Mean } & \multirow[b]{2}{*}{ SD } & \multirow[b]{2}{*}{ Range } & \multirow[b]{2}{*}{ E } & \multirow[b]{2}{*}{$\mathrm{G}$} & \multirow[b]{2}{*}{ GXE } & \multirow[b]{2}{*}{$H^{2}$} \\
\hline & & Mean & SD & Mean & SD & & & & & & & \\
\hline \multirow[t]{2}{*}{ LW1 (cm) } & Field & 0.78 & 0.04 & 0.72 & 0.04 & 0.77 & 0.06 & $0.54-0.90$ & \multirow[b]{2}{*}{$* * *$} & \multirow[b]{2}{*}{$* * *$} & \multirow[b]{2}{*}{$* * *$} & 0.73 \\
\hline & $\mathrm{GH}$ & 0.84 & 0.11 & 0.64 & 0.05 & 0.84 & 0.05 & $1.2-8.01$ & & & & 0.88 \\
\hline \multirow[t]{2}{*}{ LA1 $\left(\mathrm{cm}^{2}\right)$} & Field & 5.96 & 0.19 & 4.39 & 0.78 & 5.03 & 0.66 & $3.22-6.60$ & \multirow[b]{2}{*}{$* * *$} & \multirow[b]{2}{*}{$* * *$} & \multirow[b]{2}{*}{$* * *$} & 0.81 \\
\hline & GH & 6.72 & 1.24 & 3.79 & 0.73 & 5.81 & 0.97 & $3.0-8.01$ & & & & 0.80 \\
\hline \multirow[t]{2}{*}{ LDW1 (mg) } & Field & 21.00 & 4.00 & 17.00 & 1.00 & 21.00 & 3.00 & $0.01-0.03$ & \multirow[b]{2}{*}{$* * *$} & \multirow[b]{2}{*}{$* * *$} & \multirow[b]{2}{*}{$* * *$} & 0.78 \\
\hline & GH & 21.00 & 3.00 & 18.00 & 5.00 & 19.00 & 3.00 & $0.01-0.03$ & & & & 0.81 \\
\hline \multirow[t]{2}{*}{ SLA1 $\left(\mathrm{cm}^{2} \cdot \mathrm{g}^{-1}\right)$} & Field & 284.00 & 34.00 & 204.00 & 65.00 & 236.00 & 28.00 & $181-290$ & \multirow[b]{2}{*}{$* * *$} & \multirow[b]{2}{*}{$* * *$} & \multirow[b]{2}{*}{$* * *$} & 0.52 \\
\hline & GH & 319.00 & 46.00 & 253.00 & 37.00 & 311.00 & 34.00 & $190-541$ & & & & 0.82 \\
\hline \multirow[t]{2}{*}{ LW2 (cm) } & Field & 0.80 & 0.07 & 0.60 & 0.07 & 0.74 & 0.06 & $0.58-0.84$ & \multirow[b]{2}{*}{$* * *$} & \multirow[b]{2}{*}{$* * *$} & \multirow[b]{2}{*}{$* * *$} & 0.71 \\
\hline & GH & 0.94 & 0.05 & 0.66 & 0.05 & 0.85 & 0.05 & $0.68-1.01$ & & & & 0.82 \\
\hline LA2 $\left(\mathrm{cm}^{2}\right)$ & Field & 9.62 & 1.11 & 4.48 & 0.70 & 7.33 & 1.21 & $4.47-90.94$ & & & & 0.78 \\
\hline & $\mathrm{GH}$ & 11.29 & 1.06 & 5.06 & 0.37 & 8.79 & 1.22 & $6.16-11.68$ & $* * *$ & $* * *$ & $* * *$ & 0.79 \\
\hline LDW2 (mg) & Field & 29.00 & 0.06 & 22.00 & 1.00 & 27.00 & 6.00 & $18-39$ & & & & 0.31 \\
\hline & $\mathrm{GH}$ & 28.00 & 0.01 & 22.00 & 1.00 & 28.00 & 4.00 & $0.02-0.05$ & $* * *$ & NS & $* * *$ & 0.77 \\
\hline SLA2 $\left(\mathrm{cm}^{2} \cdot \mathrm{g}^{-1}\right)$ & Field & 335.00 & 58.00 & 197.00 & 27.00 & 298.00 & 36.00 & $206-428$ & & & & 0.81 \\
\hline & GH & 412.00 & 88.00 & 228.00 & 23.00 & 313.00 & 24.00 & $252-377$ & $* * *$ & $* * *$ & $* * *$ & 0.85 \\
\hline
\end{tabular}

\$W1 = Leaf width of the first leaf, LA1 = Leaf area of the first leaf, LDW1 = Leaf dry weight of the first leaf, LW2 = leaf width of the second leaf, LA2 $=$ Leaf area of the second leaf, LDW2 $=$ Leaf dry weight of the second leaf, SLA1 $=$ Specific leaf area of the first leaf, SLA2 $=$ Specific leaf area of the second leaf. 
Capo-chichi et al. Journal of Plant Science \& Molecular Breeding 2012, http://www.hoajonline.com/journals/pdf/2050-2389-1-2.pdf

doi: $10.7243 / 2050-2389-1-2$

Table 2 Average, minimum (min) and maximum (max) values and trait heritability of 'CDC Cowboy', 'CDC Rattan' and RILs for the following traits across environments.

\begin{tabular}{|c|c|c|c|c|c|c|c|c|c|c|}
\hline \multirow[t]{2}{*}{ Traits } & \multicolumn{2}{|c|}{ CDC Cowboy CDC Rattan } & \multicolumn{4}{|c|}{ Hulless } & \multicolumn{4}{|c|}{ Hulled } \\
\hline & Mean & Mean & Mean & Min & Max & $H^{2}$ & Mean & Min & $\operatorname{Max}$ & $H^{2}$ \\
\hline LW1 (cm) & 0.78 & 0.72 & 0.76 & 0.54 & 0.90 & 0.72 & 0.70 & 0.54 & 0.82 & 0.81 \\
\hline LA1 $\left(\mathrm{cm}^{2}\right)$ & 5.96 & 4.05 & 5.01 & 3.22 & 6.61 & 0.81 & 4.73 & 2.93 & 6.34 & 0.81 \\
\hline LDW1 (g) & 0.03 & 0.02 & 0.02 & 0.01 & 0.03 & 0.49 & 0.02 & 0.01 & 0.06 & 0.37 \\
\hline SLA1 $\left(\mathrm{cm}^{2} \cdot \mathrm{g}^{-1}\right)$ & 284.00 & 197.00 & 237.00 & 181.20 & 302.00 & 0.56 & 226.00 & 149.00 & 278.00 & 0.64 \\
\hline LW2 (cm) & 0.80 & 0.60 & 0.73 & 0.58 & 0.84 & 0.68 & 0.70 & 0.54 & 0.86 & 0.83 \\
\hline LA2 $\left(\mathrm{cm}^{2}\right)$ & 9.62 & 4.50 & 7.25 & 4.46 & 9.94 & 0.79 & 7.03 & 3.99 & 10.08 & 0.85 \\
\hline LDW2 $(\mathrm{g}$ & 0.03 & 0.02 & 0.03 & 0.02 & 0.10 & 0.32 & 0.03 & 0.01 & 0.04 & 0.54 \\
\hline $\operatorname{SLA} 2\left(\mathrm{~cm}^{2} \cdot \mathrm{g}^{-1}\right)$ & 335.00 & 253.00 & 295.00 & 207.00 & 396.00 & 0.80 & 278.00 & 208.00 & 396.00 & 0.88 \\
\hline
\end{tabular}

$\$$ LW1 = Leaf width of the first leaf, LA1 = Leaf area of the first leaf, LDW1 = Leaf dry weight of the first leaf, LW2 = leaf width of the second leaf, LA2 = Leaf area of the second leaf, LDW2 = Leaf dry weight of the second leaf, SLA1 = Specific leaf area of the first leaf, SLA2 $=$ Specific leaf area of the second leaf.
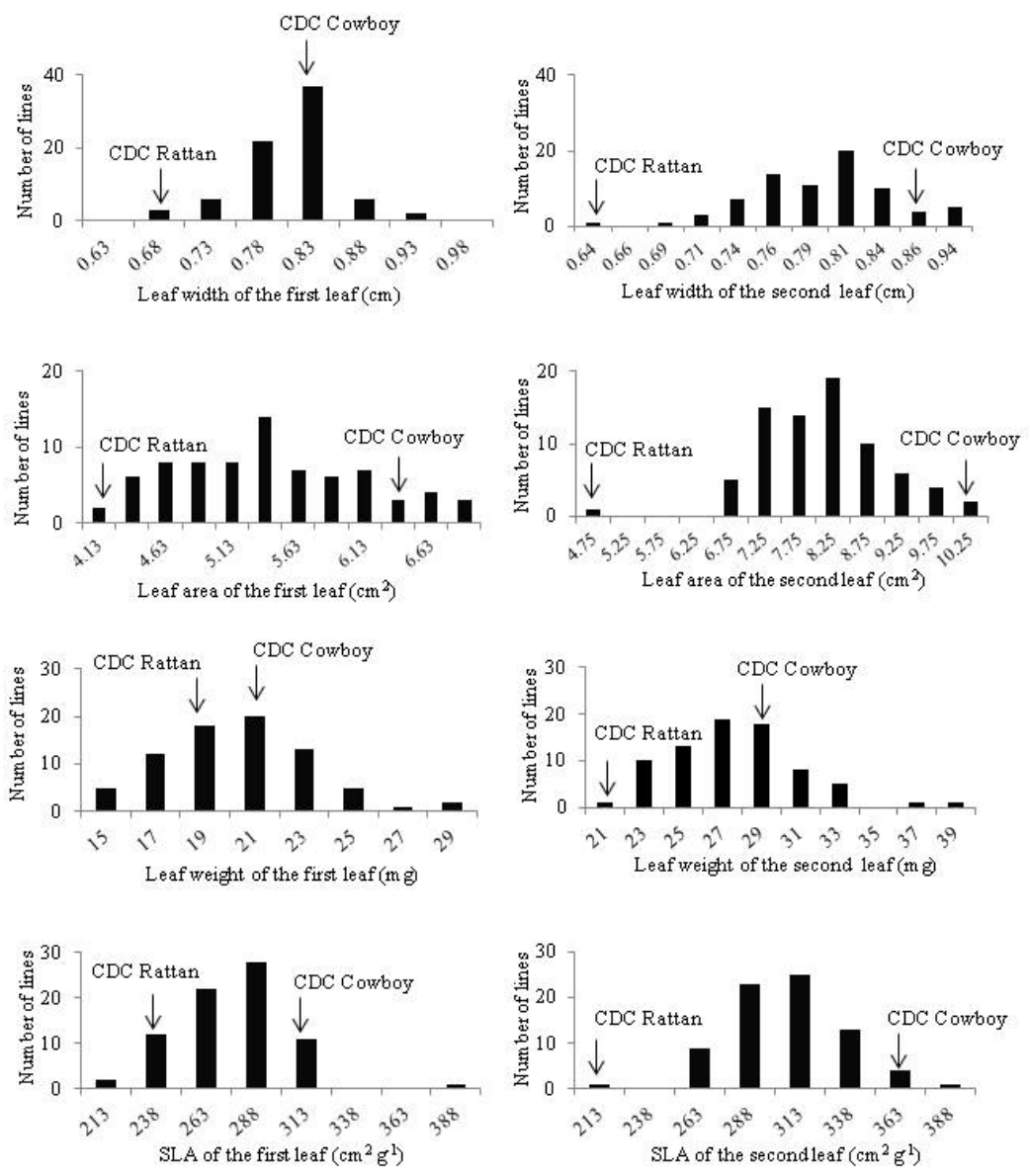

Figure 1. Frequency distribution of leaf width of the first leaf (LW1), leaf area of the first leaf (LA1), leaf dry weight of the first leaf (LDW1), leaf width of the second leaf (LW2), leaf area of the second leaf (LA2), leaf dry weight of the second leaf (LDW2), specific leaf area of the first leaf (SLA1), and specific leaf area of the second leaf (SLA2) means measured on the hulless recombinant inbred lines (RILs) from CDC Cowboy and CDC Rattan grown in the field and greenhouse. Parental means are indicated. 
Capo-chichi et al. Journal of Plant Science \& Molecular Breeding 2012,

\section{Correlation among seedling vigour related traits}

Significant correlations were observed and were relatively strong in most cases (Table 3 ). The LDW of the first and second leaves was negatively correlated with SLA1 (Table 3), but positively and moderately correlated with LW and LA. The LW was highly correlated with LA; the correlation was moderate with SLA (Table 3). The LA of the first leaf was strongly correlated with the LA of the second leaf. There was no significant correlation between LA of the first leaf or LDW of the second leaf and SLA2 (Table 3). We hypothesized that $L W$ values may be predictive of $L A$ and SLA values. We proposed that measuring the width of seedling leaves would integrate variation for SLA, and therefore, provide an efficient selection tool for early seedling vigour. In general, seedling vigour related traits of the first leaf were significantly correlated with those of the second leaf.

\section{Heritability}

Relatively high heritability values were found for LW, LA, and SLA of the first two leaves (Tables 1 and 2), while the lowest to moderate values were found for LDW of the first and second leaves and the number of coleoptile tillers and stem tillers (Table 2). The broad sense heritability ranged from 0.30 for the number of coleoptile tillers to 0.88 for SLA2 and LW1 (Tables 1 and 2). The high heritability ranging from 0.71 to 0.88 indicates the genetic stability of the associated traits across generations. The heritability for SLA2, SLA1, LW1, LA1, LDW1, LW2, LA2, and LDW2 appeared stable across environments (Table 2). Results show that heritability for SLA1, LDW1, and LDW2 were small (Table 1). However, LW1 averaged across environments was highly heritable and had significant correlations with SLA1 and $\mathrm{LA} 1(r=0.34$ and 0.74 , respectively). The combination of high heritability and significant correlations suggests that LW1 can be used as an indirect measure of SLA1 and LA1.
Measuring LW1 is rapid, non-destructive and can be used on large number of seedlings.

\section{Discriminant analyses}

The canonical discriminant analysis revealed that the first three discriminant functions accounted for $69 \%$ of the total observed variance among the response variables (Table 4). The centroid values for the first two canonical functions for the RIL population plotted in Figure 2 show significant $(P<0.001)$ canonical correlation between the RILs and the three canonical variates $\left(r_{1}=0.90, r_{2}=0.79\right.$, and $r_{3}=0.75$, respectively). This indicates that the canonical variates can explain the differentiation of the lines. The first discriminant function is dominated by a large loading from LDW1 and LW2 (Table 4). The second function is dominated by a large loading from LDW1 and SLA2. The third function is dominated by a large loading of LA1, LDW1, SLA1, and LW1 (Table 4). This suggests that the genetic variation of the RILs differ mainly in LA1, LW2, LA1, LDW1, SLA1, LW1, and SLA2. In spite of the loadings from the traits dominating the discriminant functions, the hulless RILs could not be separated from the hulled RILs (Figure 2), indicating that the nud locus is not the underlying biological component influencing the canonical functions.

\section{Discussion}

\section{The nud locus on seedling vigour related traits}

One of the most important considerations in this study was to investigate to what extent the nud locus would affect seedling vigour related traits in barley. The hulled/ hulless caryopsis in barley is controlled by a single locus (nud, for nudum) located on chromosome arm $7 \mathrm{HL}$; the hulled caryopsis allele (Nud) is dominant over the hulless one (nud) [32]. Previous research has shown that hullessness is associated with short plant height, poor emergence, low seed weight, and low grain yield, but does not affect

Table 3 Pearson's phenotypic correlation among traits measured in the hulless RIL population grown in the field and greenhouse

\begin{tabular}{|l|l|l|l|l|l|r|r|r|r|}
\hline Trait: & LW1 & LA1 & LDW1 & SLA1 & LW2 & LA2 & LDW2 & SLA2 \\
\hline LW1 & 1 & $0.735 * * *$ & $0.349 * * *$ & $0.343 * * *$ & $0.663 * * *$ & $0.529 * * *$ & $0.162 * * *$ & $0.165 * * *$ \\
\hline LA1 & & 1 & $0.625 * * *$ & $0.323 * * *$ & $0.626 * * *$ & $0.731 * * *$ & $0.299 * * *$ & $0.077 \mathrm{~ns}$ \\
\hline LDW1 & & & 1 & $-0.459 * * *$ & $0.256 * * *$ & $0.420 * * *$ & $0.317 * * *$ & $-0.250 * * *$ \\
\hline SLA1 & & & & 1 & $0.348 * * *$ & $0.276 * * *$ & $-0.036 * * *$ & $0.351 * * *$ \\
\hline LW2 & & & & & 1 & $0.783 * * *$ & $0.238 * * *$ & $0.298 * * *$ \\
\hline LA2 & & & & & & 1 & $0.399 * * *$ & $0.303 * * *$ \\
\hline LDW2 & & & & & & & 1 & $0.006 \mathrm{~ns}$ \\
\hline SLA2 & & & & & & & & 1 \\
\hline
\end{tabular}

\$W1 = Leaf width of the first leaf, LA1 = Leaf area of the first leaf, LDW1 = Leaf dry weight of the first leaf, LW2 = leaf width of the second leaf, LA2 = Leaf area of the second leaf, LDW2 = Leaf dry weight of the second leaf, SLA1 = Specific leaf area of the first leaf, SLA2 $=$ Specific leaf area of the second leaf.

${ }^{\star},{ }^{* *},{ }^{* *}=$ significant at $0.05 ; 0.01$; and 0.001 probability level, respectively ns $=$ non significant 
Table 4 The canonical loadings of the independent variables on the first three canonical discriminant variates of the hulless RILs. The study was conducted in the field and greenhouse.

\begin{tabular}{|l|r|r|r|}
\hline \multirow{2}{*}{ Trait $\ddagger$} & \multicolumn{3}{|c|}{ Canonical discriminant variate } \\
\cline { 2 - 4 } & 1 & 2 & 3 \\
\hline LW1 & 0.58 & 0.6 & -1.05 \\
\hline LA1 & 0.61 & -0.4 & 2.6 \\
\hline LDW1 & -1.74 & 1.42 & -1.53 \\
\hline SLA1 & 0.08 & 0.4 & -1.06 \\
\hline LW2 & 1.31 & -0.43 & -0.48 \\
\hline LA2 & 0.08 & -0.13 & 0.89 \\
\hline LDW2 & -0.08 & 0.07 & -0.06 \\
\hline SLA2 & -0.33 & 1.28 & -0.42 \\
\hline Eigenvalue & 4.47 & 1.74 & 1.32 \\
\hline Cumulative \% & 0.41 & 0.57 & 0.69 \\
\hline Canonical correlation & 0.9 & 0.79 & 0.75 \\
\hline P level of significance & 0.001 & 0.001 & 0.001 \\
\hline
\end{tabular}

\$W1 = Leaf width of the first leaf, LA1 = Leaf area of the first leaf, LDW1 = Leaf dry weight of the first leaf, LW2 = leaf width of the second leaf, LA2 = Leaf area of the second leaf, LDW2 = Leaf dry weight of the second leaf, SLA1 = Specific leaf area of the first leaf, SLA2 $=$ Specific leaf area of the second leaf.

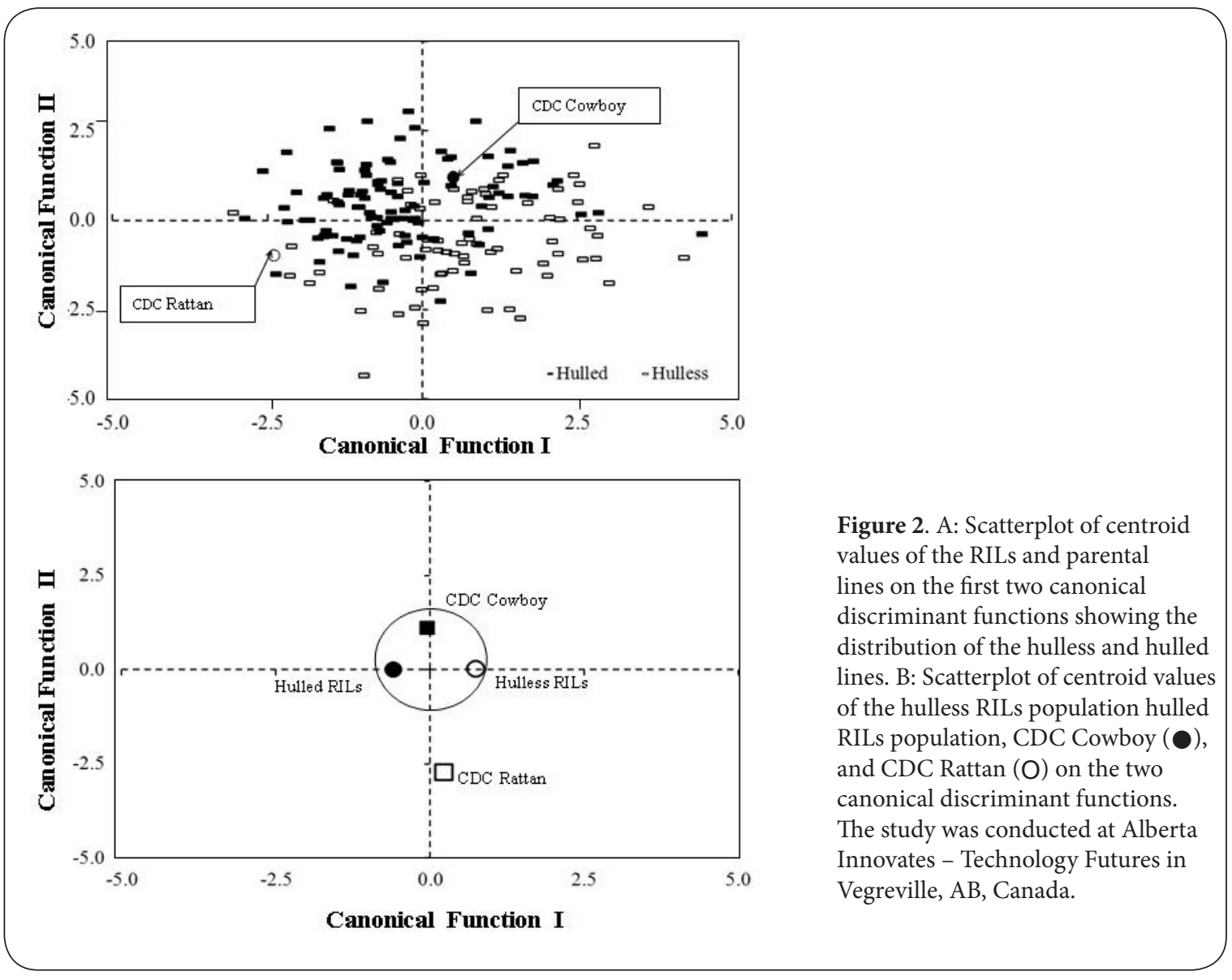


maturity, heading date, spike density, smut resistance, and scald resistance [19]. In the present study, although the two parental varieties, CDC Cowboy, a hulled type, and CDC Rattan, a hulless type, showed significant differences in seedling vigour related traits under field and greenhouse environments, several hulless RILs were not significantly different from the hulled parental variety, suggesting that the nud locus was not associated with the traits. Though the hulled parent had greater seedling vigour than the hulless parent, some of the hulless RILs produced higher seedling vigour values than the hulled parental variety.

Effects of environment on seedling vigour related traits Among CDC Cowboy and the hulless RILs, the effects of environment were significantly larger on SLA than on LW, LA, and LDW which showed insignificant variations across environments. The variations for seedling vigour related traits were smaller among CDC Rattan plants, showing stability of the traits across environments. The influence of environment on SLA was consistent with previous studies $[33,10,7]$ where plants grown under greenhouse environments produced greater SLA values than field grown plants. Several environmental factors have been proposed to affect SLA, including air temperature [30], light quality and light intensity $[34,35]$. High humidity and low wind speed have been suggested as an explanation as to why individual plants respond to low light levels with an increase in SLA [36]. Environments associated with greater SLA1 and SLA2 were found to be associated with greater LA1 and LA2, indicating positive environmental correlations. Similar results were obtained by [10], who investigated the nature and repeatability of gene actions for SLA in segregating wheat populations. The genotypic differences observed for SLA suggest that it is possible to breed hulless barley for high SLA through recombination. CDC Cowboy could be an excellent donor for larger SLA.

\section{Sources of genetic variation}

The results indicated that the hulled $X$ hulless cross generated wide genetic variations for the seedling vigour related traits and showed evidence for transgressive segregation. The traits differed among genotypes and for most of the RILs, but the ranking remains the same across environments. Transgressive segregation is defined as the appearance of individuals in segregating populations that fall beyond their parental phenotypes [37-39]. Our results showed that RILs had a mean value outside the parental lines, suggesting polygenic control for seedling vigour related traits and the possibility that independent alleles at two or more loci can be combined to increase trait values. This could be explained in most cases as a result of complementary genes, along with the contribution of epistasis and overdominance [38]. A recent review of phenotypic variation in hybrids indicates that transgressive segregation occurs frequently in segregating plant populations [38]. Out of 171 studies reviewed, 155 (91\%) reported at least one transgressive trait and $44 \%$ of 1229 traits examined were transgressive [40]. RIL populations often show transgressive segregation, even when the parents are phenotypically similar [37]. Heritability and correlation between traits can show the extent to which these traits are genetically determined and which of them contribute to the selection and cultivar development. Relatively high heritability values were obtained for all traits, suggesting that these traits can be improved through conventional breeding. A high estimate of heritability for leaf width has been reported by [41]. The SLA has relatively low heritability in cereals [10], suggesting that its value as a selection tool for high early vigour may be limited. The difference in heritability values obtained for SLA in this study, compared to the values reported by [10], can be explained by the fact that heritability depends on many factors, such as the environmental conditions. Correlation coefficients among the seedling vigour related traits were significant, reflecting the effectiveness of indirect selection that can be used to improve any of these traits. The seedling vigour related traits tended to be positively correlated when they were investigated under similar environments [42]. In this work, the LW exhibited highly significant positive associations with LA and SLA, suggesting that selection of LW with desirable LA or SLA is possible. The higher heritability for LW and its strong association with SLA and LA under field and greenhouse environments indicates that LW can integrate the genotypic variation of SLA and LA toward selection of greater seedling vigour. The early seedling vigour of barley previously reported in field and control environments $[3,33,5]$ was observed in the current study. At the initial stage of early seedling growth, leaf dry matter is largely dependent on the seed reserves [43]. A highly significant and positive correlation exists between seed weight and leaf dry matter accumulation [44]. Considering the strong genetic control of the LW, LA and SLA, these traits could be used to improve early seedling vigour in hulless barley.

\section{Conclusion}

Significant variation among seedling vigour related traits exists in both hulless and hulled RILs of the study barley population set. We have shown that segregation of these RILs exhibit wide variable phenotypes when compared to parental values for the seedling vigour related traits. Several of the hulless RILs showed much greater seedling vigour, translating into higher rates of plant establishment. Hulless RILs derived from CDC Cowboy, the hulled parental type, appeared to retain this vigour, suggesting that it may be possible to develop hulless barley with high seedling vigour which may overcome the establishment problems of hulless barley. Therefore, CDC Cowboy could be a potential source of genetic traits of seedling vigour in a hulless barley breeding program. Additional crosses should be made using different parental sources of seedling vigour. 
Such crosses could be used to determine if similar results are obtained or if results of this study are a consequence of specific interactions between the parents used. The hulled/hulless caryopsis controlled by the locus nud was found not to be associated with the seedling vigour related traits. This study showed that genetic gain from selection for early seedling vigour is likely to be greatest through selection for leaf area and leaf width and it is possible to breed hulless barley for high seedling vigour.

\section{Competing interests}

The authors declare that they have no competing interests.

\section{Acknowledgements}

This work was supported by the Alberta Crop Industry Development Fund (ACIDF) and a fellowship granted to L.A.J. Capo-chichi from Alberta Ingenuity Fund. We are grateful to the staff of Alberta Innovates - Technology Futures (formerly Alberta Research Council) for the technical support and Field Crop Development Centre (FCDC), Lacombe, for providing the genetic materials used in this study.

\section{Authors' contribution}

The research project was conducted under

the supervision of KDK and AOA,

Cash and In-Kind contribution by the authors of the manuscript: Dr. Joseph Nyachiro and Dr. Anthony O. Anyia have screened several barley germplam and identified the parental lines used in the study. Dr. Nyachiro has made the cross between the parental lines and made the F1 generation available for the project. I have developed the RILs derived from the F1 hybrid by single seed descend. The screening for seedling vigour related traits was done in both the laboratories of Dr. Kenward at 20/20 Seed Labs Inc. in Nisku and Dr. Anyia at Alberta Innovates - Technology Future in Vegreville.

\section{Publication history}

Editor: Xianming Chen, Washington State University USA.

Received: 18-Aug-2012 Revised: 19-Sep-2012

Accepted: 15-Oct-2012 Published: 25-Oct-2012

\section{References}

1. Richards RA: Selectable traits to increase crop photosynthesis and yield of grain crops. J Exp Bot 2000, 51 Spec No:447-458. | Article | PubMed

2. Richards RA, Rebetzke GJ, Condon AG, van Herwaarden AF: Breeding Opportunities for Increasing the Efficiency of Water Use and Crop Yield in Temperate Cereals. Crop Sci 2002, 42:111-121. | Article | PubMed

3. López-Castañeda C, Richards RA: Variation in temperate cereals in rainfed environments. III. Water use and water-use efficiency. Field Crops Research 1994, 39:85-98. | Article

4. Pandey MP, Seshu DV, Akbar M: Genetics of embryo size and its relationships with seed and seedling vigour in rice (Oryza sativa L.). Plant Breeding 1994, 54:258-268. | Article

5. López-Castañeda C, Richards RA, Farquhar GD, Williamson RE: Seed and seedling characteristics contributing to variation in early vigour among temperate cereals. Crop Science 1996, 36:1257-1266. I Article
6. Dingkuhm M, Jones MP, Johnson DE, Sow A: Growth and yield potential of Oryza sativa and $O$. glaberrima upland rice cultivars and their interspecific progenies. Field Crops Research 1998, 57:57-69. | Article

7. Richards RA, Lukacs Z: Seedling vigour in wheat-sources of variation for genetic and agronomic improvement. Australian Journal of Agricultural Research 2002, 53:41-50. | Article

8. Richards RA: Defining selection criteria to improve yield under drought. Plant Growth Regul 1996, 20:157-166. | Article

9. Bort J, Araus JL, Hazzam H, Grando S, Ceccarelli S: Relationships between early vigour, grain yield, leaf structure and stable isotope composition in field grown barley. Plant Physiology and Biochemistry 1998, 36:889-897. | Article

10. Rebetzke GJ, Botwright TL, Moore CS, Richards RA, Condon AG: Genotypic variation in specific leaf area for genetic improvement of early vigour in wheat. Field Crop Research 2004, 88:179-189. | Article

11. Trachsel S, Messmer R, Stamp P, Ruta N, Hund A: QTLs for early vigor of tropical maize. Mol Breeding 2010, 25:91-103. | Article

12. Rebetzke GJ, Richards RA (1996) Improving the establishment and early vigour of wheat. In 'Proceedings of the 8th Australian Agronomy Conference'. (Ed. M Asghar) pp. 466-469. The Australian Society of Agronomy: Toowoomba, Qld.

13. Rebetzke GJ, Richards RA: Genetic improvement of early vigour in wheat. Australian Journal of Agricultural Research 1999, 50:291-301. | Article

14. Powell W, Ellis RP, Thomas WTB: The effects of major genes on quantitatively varying characters in barley.: III. The two row//six row locus (V-v). Heredity 1990, 65:259-264. | Article

15. Kjær B, Jensen J: Quantitative trait loci for grain yield and yield components in a cross between a six-rowed and a two-rowed barley. Euphytica 1996, 90:39-48. I Article

16. Marquez-Cedillo LA, Hayes PM, Jones BL, Kleinhofs A, Legge WG, Rossnagel BG, Sato K, Ullrich SE, Wesenberg DM, North American Barley Genome Mapping P: QTL analysis of malting quality in barley based on the doubled-haploid progeny of two elite North American varieties representing different germplasm groups. Theoretical and Applied Genetics 2000, 101:173-184. I Article

17. Heun M: Mapping quantitative powdery mildew resistance of barley using a restriction fragment length polymorphism map. Genome 1992, 35:1019-1025. | Article | PubMed Abstract | PubMed Full Text

18. Pecchioni N, Vale G, Toubia-Rahme H, Faccioli P, Terzi V, Delogu G: Barley-Pyrenophora graminea interaction: QTL analysis and gene mapping. Plant Breeding 1999, 118:29-35. | Article

19. Choo TM, Ho KM, Martin RA: Genetic analysis of a hulless $\mathbf{X}$ covered cross of barley using double-haploid lines. Crop Science 2001, 41:1021-1026. | Article

20. Kibite S, Taylor JS: Inheritance and linkage relationships of genes conditioning hullessness, multiflorous spikelet, and giantism in oat (Avena sativa L.). Canadian Journal of Plant Science 1994, 74:497-500. | Article Text

21. McGuire CF, Hockett EA: Effect of awn length and naked caryopsis on malting quality of betzes barley. Crop Science 1981, 21:18-21. | Article

22. Takahashi R, Inamura H, Matsumoto T (1961) Effects of the genes for covered and naked kernels on some agronomic characters in barley. Ber. Ohara Inst. Landwirtch. Bio. Okayama Univ. 11: 385-392.

23. Boland $P$, Lawes DA: The inheritance of the naked grain character in oats studied in a cross between the naked variety caesar and the husked variety BO 1/11. Euphytica 1973, 22:582-591. | Article

24. Lawes DA, Boland P: Effect of temperature on the expression of the naked grain character in oats. Euphytica 1974, 23:101-104. | Article

25. Toker C, Ilhan Cagirgan M: The use of phenotypic correlations and 
factor analysis in determining characters for grain yield selection in chickpea (Cicer arietinum L.). Hereditas 2004, 140:226-228. | Article I PubMed

26. Toker C, Cagirgan IM (2003) Selection criteria in chickpea (Cicer arietinum). Acta Agric. Scand. Sect. B, Soil Plant Science 53: 42-45.

27. Powell W, Thomas WTB, Caligari PDS, Jinks JL: The effects of major genes on quantitatively varying characters in barley 1 . The GP ert locus. Heredity 1985, 54:343-348. | Article

28. Powell W, Caligari PDS, Thomas WTB, Jinks JL: The effects of major genes on quantitatively varying characters in barley 2 . The denso and daylength response loci. Heredity 1985, 54:349-352. | Article

29. SAS Institute, (2003) The SAS system for Windows. Release 9.1. SAS Institute Inc. Cary, NC, USA.

30. Hotelling $\mathrm{H}$ : Relations between two sets of variates. Biometrika 1936, 28:321-377. | Article

31. Vaylay R, van Santen E: Application of canonical discriminant analysis for the assessment of genetic variation in tall fescue. Crop Science 2002, 42:534-539. I Article

32. Franckowiack JD, Konishi T: Naked caryopsis. Barley Genet. Newsletter 26:51-52. | Article

33. López-Castañeda C, Richards RA, Farquhar GD: Variation in early vigour between wheat and barley. Crop Science 1995, 35:472-479. I Article | PubMed Abstract | PubMed Full Text

34. Casal JJ, Aphalo PJ, Sanchez RA: Phytochrome effects on leaf growth and chlorophyll content in Petunia axilaris. Plant Cell Environment 1987, 10:509-514. | Article

35. Friend DJC, (1966) The effects of light and temperature on the growth of cereals. In: Milthorpe, F.L. and J.D. Ivins (eds), The Growth of Cereals and Grasses. Butterworths. London, pp. 181-199.

36. Givnish TJ, Montgomery RA, Goldstein G: Adaptive radiation of photosynthetic physiology in the Hawaiian lobeliads: light regimes, static light responses, and whole-plant compensation points. Am J Bot 2004, 91:228-246. | Pdf | PubMed

37. deVicente MC, Tanksley SD: QTL analysis of transgressive segregation in an interspecific tomato cross. Genetics 1993, 134:585-596. | Article | PubMed Abstract | PubMed Full Text

38. Rieseberg LH, Archer MA, Wayne RK: Transgressive segregation, adaptation and speciation. Heredity (Edinb) 1999, 83 ( Pt 4):363-372. I Article I PubMed

39. Hagiwara WE, Onishi K, Takamure I, Sano Y: Transgressive segregation due to linked QTLs for grain characteristics of rice. Euphytica 2006, 150:27-35. | Article

40. Rieseberg LH, Widmer A, Arntz AM, Burke JM: The genetic architecture necessary for transgressive segregation is common in both natural and domesticated populations. Philos Trans R Soc Lond B Biol Sci 2003, 358:1141-1147. | Article | PubMed Abstract | PubMed Full Text

41. Gupta D, Basak SL: Genetics of germination and seedling growth of flax (Linum usitatissimum). Seed Science and Technology 1983, 11:251-256. | Article

42. Zhang ZH, Qu XS, Wan S, Chen LH, Zhu YG: Comparison of QTL controlling seedling vigour under different temperature conditions using recombinant inbred lines in rice (Oryza sativa). Ann Bot 2005, 95:423429. | Article | PubMed

43. Yoshida, S: Fundamentals of rice crop science. Los Baños (Philippines): International Rice Research Institute 1981, 269 p. | Book

44. Cui H, Peng B, Xing Z, Xu G, Yu B, Zhang Q: Molecular dissection of seedling-vigor and associated physiological traits in rice. Theor Appl Genet 2002, 105:745-753. | Article | PubMed 